\title{
PENGGUNAAN MEDIA AUDIO VISUAL DALAM PEMBELAJARAN ANAK USIA DINI
}

\author{
Ayu Fitria ${ }^{1}$
}

\begin{abstract}
ABSTRAK
Anak usia dini merupakan usia emas. Pada usia ini diperhatikan tugas perkembangannya. Media pembelajaran akan membantu keefektifan proses pembelajaran dalam penyampaian pesan dan isi pelajaran. Terkadang guru mengabaikan dalam penggunaan media, padahal dengan menggunakan media pembelajaran khususnya media audio visual. Bertujuan untuk motivasi belajar anak sehingga mudah penangkapan isinya oleh anak. Langkah dalam pembelajaran menggunakan media audio visual, mempersiapkan laptop, sound, kabel dan video yang akan ditayangkan, memperhatikan posisi duduk peserta didik dalam keadaan nyaman dan pada saat akan mengajak peserta didik menyimak video, guru menyampaikan tujuan pembelajaran dan teknis pembelajaran, kemudian peserta didik siap menyaksikan tayangan video dan diberikan tindak lanjut berupa pertanyaan berkaitan dengan isi video.
\end{abstract}

\section{A. PENDAHULUAN}

Pendidikan dalam arti luas adalah hidup. Maksudnya bahwa pendidikan adalah segala pengalaman belajar di berbagai lingkungan yang berlangsung sepanjang hayat dan berpengaruh positif bagi perkembangan individu. Dalam hal ini pendidikan diarahkan untuk membantu peserta didik memperoleh pengalaman belajar yang bermakna dalam setiap pembelajaran yang dilaluinya di lingkungan belajar. Pembelajaran yang berlangsung sepanjang hayat ini diharapkan mampu memberikan nilai-nilai positif guna mengarahkan perkembangan peserta didik ke arah kemajuan dan mampu memandirikan peserta didik dalam menempuh pengajaran sepanjang hayat.

Dalam Pasal 3 Undang-undang RI Nomor 20 tahun 2003 diungkapkan bahwa pendidikan nasional berfungsi untuk mengembangkan kemampuan dan membentuk watak serta peradaban bangsa yang bermartabat dalam rangka mencerdaskan kehidupan bangsa, yang bertujuan untuk berkembangnya potensi siswa agar menjadi manusia yang beriman dan bertaqwa kepada Tuhan Yang Maha Esa, berakhlak mulia, sehat, berilmu, cakap, kreatif, mandiri, dan menjadi warga Negara yang demokratis serta bertanggung jawab. Tujuan yang dimaksud, pada intinya adalah pembentukan pribadi manusia yang utuh.

Anak usia dini merupakan usia emas. Pada usia ini diperhatikan tugas perkembangannya. Media pembelajaran akan membantu keefektifan proses pembelajaran dalam penyampaian pesan dan isi pelajaran. Terkadang guru mengabaikan dalam penggunaan media, padahal dengan menggunakan media pembelajaran khususnya media audio visual membuat anak termotivasi dalam belajar dan mudah penangkapan isinya oleh anak. Berdasarkan latar belakang di

${ }^{1}$ Mahasiswa Sekolah Pascasarjana UPI 
atas, melalui makalah ini penulis akan memaparkan materi mengenai media pembelajaran menggunakan media audio visual.

Berdasarkan latar belakang di atas, makalah ini bertujuan untuk memaparkan (1) pengertian media pembelajaran; (2) tujuan media pembelajaran; (3) fungsi media pembelajaran; (4) manfaat media pembelajaran; (5) landasan penggunaan media dalam pembelajaran; (6) klasifikasi media pembelajaran; dan (7) penggunaan media audio visual. Keseluruhan pembahasan ini dibatasi dalam konteks pendidikan anak usia dini.

\section{B. PEMBAHASAN}

\section{Hakikat Media Pembelajaran}

Kata media pembelajaran bentuk jamak dari kata medium. Menurut Heinich (Daryanto, 2010: 12) 'medium dapat didefinisikan sebagai perantara atau pengantar terjadinya komunikasi dari pengirim menuju penerima'. Sementara menurut Criticos (Daryanto, 2010: 12) 'media merupakan salah satu komponen komunikasi, yaitu sebagai pembawa pesan dari komunikator menuju komunikan'. Berdasarkan definisi tersebut, dapat dikatakan bahwa media adalah perantara yang menghubungkan suatu pesan dari pengirim menuju penerima.

Menurut Scramm (Hermawan, 2009: 11) mengemukakan bahwa 'media adalah teknologi pembawa pesan yang dapat dimanfaatkan untuk keperluan pembelajar: Jadi media pembelajaran adalah alat yang berfungsi untuk menyampaikan pe pembelajaran dari seorang guru kepada peserta didik.

Pembelajaran anak usia dini selalu disajikan dengan ceramah. Dalam otak peserta didik terkadang mulai jenuh, dengan demikian guru harus mencari inovasi yang baru untuk meningkatkan motivasi belajar peserta didik, ketika peserta didik termotivasi belajar maka hasil belajar pun akan meningkat. Salah satunya dengan menggunakan media dalam proses pembelajaran. Jadi dengan penggunaan media pembelajaran dapat membatu untuk membangkitkan motivasi belajar peserta didik.

Menurut Sanaky (2011: 4) tujuan media pembelajaran sebagai alat bantu pembelajaran, adalah sebagai berikut:

a. Mempermudah proses pembelajaran di kelas

b. Meningkatkan efisiensi proses pembelajaran

c. Menjaga relevansi antara materi pelajaran dengan tujuan belajar, dan

d. Membantu konsentrasi pembelajar dalam proses pembelajaran

Jadi tujuan penggunaan media pembelajaran adalah memudahkan guru dalam menyampaikan sebuah materi pelajaran, sehingga dapat mengefisiensikan proses pembelajaran dan membantu peserta didik dalam menerima sebuah konsep atau materi ajar.

Menurut Sanaky (2011: 5) juga menyebutkan bahwa manfaat media pemebelajaran sebagai alat bantu dalam proses pembelajaran adalah sebagai berikut: a. Pengajaran lebih menarik perhatian siswa sehingga dapat menumbuhkan motivasi belajar

b. Bahan pengajaran akan lebih jelas maknanya, sehingga dapat lebih dipahami siswa, serta memungkinkan pembelajar menguasai tujuan pengajaran dengan baik 
c. Metode pembelajaran bervariasi, tidak semata-mata hanya komunikasi verbal melalui penuturan kata-kata lisan pengajar (guru), siswa tidak bosan, dan pengajar tidak kehabisan tenaga

d. Siswa lebih banyak melakukan kegiatan belajar, sebab tidak hanya mendengarkan penjelasan dari pengajar (guru) saja, tetapi juga aktifitas lain yang dilakukan seperti: mengamati, melakukan, mendemonstrasikan, dan lain-lain.

Jadi manfaat dari penggunaan media pembelajaran adalah memberikan pembelajaran yang menarik sehingga dapat menumbuhkan motivasi dalam belajar, karena bahan yang disajikan lebih jelas maknanya dan tidak bosan dalam menyerap materi ajarnya. Sehingga dapat meningkatkan hasil belajar.

Berkenaan dengan fungs media Daryanto (2010:10) menjelaskan bahwa fungsi media dalam proses pembelajaran adalah sebagai berikut:

a. Menyaksikan benda yang ada atau peristiwa yang terjadi pada masa lampau

b. Mengamati benda/peristiwa yang sukar dikunjungi, baik karena jarak jauh, berbahaya, atau terlarang.

c. Dengan mudah membandingkan sesuatu.

Media pembelajaran mempunyai fungsi sebagai alat untuk mengamati suatu benda/ peristiwa yang terjadi di masa lalu atau sukar dikunjungi, meskipun jaraknya jauh bisa dilihat dengan memperoleh gambaran yang nyata tentang suatu peristiwa.

Bertemali dengan fungsi media di atas, menurut Daryanto (2010:12) ada beberapa tinjauan tentang landasan penggunaan media pembelajaran, antara lain landasan filosofis, psikologis, teknologis, dan empiris.

a. Landasan filosofis berpendapat bahwa dengan adanya berbagai media pembelajaran justru siswa dapat mempunyai banyak pilihan untuk digunakan media yang lebih sesuai dengan karakteristik.

b. Landasan psikologis menyatakan bahwa anak akan lebih mudah mempelajari hal yang konkrit ketimbang yang abstrak.

c. Landasan teknologi merupakan proses kompleks dan terpadu yang melibatkan orang, prosedur, ide, peralatan, dan organisasi untuk menganalisis masalah, mencari cara pemecahan, melaksanakan, mengevaluasi, dan mengelola pemecahan masalah-masalah dalam situasi dimana kegiatan belajar mempunyai tujuan dan terkontrol.

d. Landasan empiris yaitu pemilihan media pembelajaran hendaknya atas dasar kesukaan guru, tetapi harus mempertimbangkan kesesuaian antara karakteristik pembelajar, karakteristik materi pelajaran, dan katakteristik media itu sendiri.

Landasan penggunaan media pembelajaran harus memperhatikan batasan usia peserta didik, materi yang akan diajarkan, sehingga peserta didik mudah dalam menangkap pesan yang disampaikan oleh suatu media tersebut.

Berdasarkan jenisnya media pembelajaran dibagi ke dalam tiga jenis pertama media audio, yaitu media hanya mengandalkan kemampuan suara saja, seperti tape recorder. Kedua media visual, yaitu media yang hanya mengandalkan indra penglihatan dalam wujud visual. Kemudian ketiga media audiovisual, yaitu media yang mempunyai unsur suara dan unsur gambar

Dalam penelitian ini yang diangkat adalah penggunaan media audio visual yaitu media yang didalamnya terdapat unsur suara dan gambar, dimana gambar 
yang disajikan adalah tayangan gambar bergerak, sedangkan suara yang dikeluarkan berdasarkan suara yang keluar dari gambar tersebut.

\section{Media Audio Visual}

Menurut Anderson (1994:99), media audio visual adalah merupakan rangkaian gambar elektronis yang disertai oleh unsur suara audio juga mempunyai unsur gambar yang dituangkan melalui pita video. Rangkaian gambar elektronis tersebut kemudian diputar dengan suatu alat yaitu video cassette recorder atau video player. Sedangkan Barbabara (Miarso, 1994: 41) mengemukakan bahwa media audio visual adalah cara memproduksi dan menyampaikan bahan dengan menggunakan peralatan mekanis dan elektronis untuk menyajikan pesan-pesan audio visual.

Sesuai dengan namanya, media audio visual merupakan kombinasi atau perpaduan audio dan visual. Sudah barang tentu apabila menggunakan media ini akan semakin lengkap dan optimal untuk menunjang kegiatan pembelajaran dan penyajian bahan ajar kepada peserta didik, selain itu dengan media ini dalam batasan tertentu dapat menggantikan peran dan tugas guru. Dalam hal ini, guru tidak selalu berperan sebagai penyaji materi tetapi karena penyajian materi bisa digantikan oleh media, maka peran guru bisa beralih menjadi fasilitator belajar, yaitu memberikan kemudahan bagi peserta didik untuk belajar. Contoh dari media audio visual diantaranya program video/televisi pendidikan, video/televisi instruksional, dan program slide suara. Jadi pembelajaran menggunakan media audio visual dapat menyampaikan pesan pembelajaran. Adanya unsur audio memungkinkan siswa untuk dapat menerima pesan pembelajaran melalui pendengaran, sedangkan unsur visual memungkinkan penciptaan pesan belajar melalui bentuk visualisasi. Media ini juga berisikan gambar-gambar yang hidup dengan diproyeksikan melalui lensa projektor secara mekanis dan menggunakan sound untuk mengeluarkan suaranya.

Anderson (1994:102) mengemukakan tentang beberapa tujuan dari pembelajaraan mengunakan media audio visual, antara lain:

Untuk tujuan kognitif adalah (a) dapat mengembangkan mitra kognitif yang menyangkut kemampuan mengenal kembali dan kemampuan memberikan rangsangan gerak dan serasi, (b) dapat menunjaukan serangkaian gambar diam tanpa suara sebagai media foto dan film bingkai meskipun kurang ekominis, (c) melalui media audio visual dapat pula diajarkan pengetahuaan tentang hukumhukum dan prinsip - prinsip tertentu. (d) media audio visual dapat digunakan untuk menunjukan contoh dan cara bersikap atau berbuat dalam suatu penampilan, khususnya yang menyangkut interaksi siswa. Untuk tujuan afektif (a) media audio visual merupakan media yang baik sekali untuk menyampaikan informasi dalam matra afektif, (b) dapat menggunakan efek dan teknik, media audio visual dapat menjadi media yang sangat baik dalam mempengaruhi sikap dan emosi. Untuk tujuan psikomotorik (a) media audio visual merupakan media yang tepat untuk memperlihatkan contoh ketrampilan yang menyangkut gerak. (b) dengan alat ini dijelaskan, baik dengan cara memperlambat maupun mempercepat gerakan yang ditampilkan. 
Tujuan dari penggunaan media audio visual untuk mengembangkan kemampuan kognitif dengan memberikan rangsangan berupa gambar bergerak dan suara, serta menyampaikan pesan untuk mempengaruhi sikap dan emosi.

Berdasarkan tujuan di atas, manfaat media audio visual bagi proses pembelajaran berguna untuk:

a. Menarik perhatian peserta didik dalam menyampaikan materi ajar

b. Menumbuhkan motivasi belajar

c. Memberikan pengalaman belajar dengan menyimpulkan pembelajaran dari sebuah video yang disajikan

Sejalan tujuan dan fungsinya, media audio visual memiliki kelebihan dan kekurangan. Kelebihannya meliputi (a) dapat digunakan untuk klasikal, (b) dapat digunakan seketika, (c) digunakan secara berulang, (d) dapat menyajikan materi secara fisik tidak dapat bicara ke dalam kelas, (e) dapat menyajikan objek yang bersifat bahaya, (f) dapat menyajikan objek secara detail, (g) tidak memerlukan ruang gelap, (h) dapat di perlambat dan dipercepat, (i) menyajikan gambar dan suara. Adapun kelemahan media audio video adalah (a) sukar untuk dapat direvisi, (b) relatif mahal, (c) memerlukan keahlian khusus, (d) peralatan harus lengkap.

Langkah penggguanaan media audio visual dalam pembelajaran anak usia dini adalah sebagai berikut.

a. Mempersiapkan laptop, sound, kabel dan video yang akan ditayangkan

b. Memperhatikan posisi duduk peserta didik dalam keadaan nyaman

c. Pada saat akan mengajak peserta didik menyimak video, guru menyampaikan tujuan pembelajaran dan teknis pembelajaran

d. Kemudian peserta didik siap menyaksikan tayangan video

\section{PENUTUP}

Pembelajaran dengan menggunakan media audio visual berkaitan dengan indera penglihatan dan pendengaran sehingga dapat mengefektifkan kemampuan alat indera anak dan anak dengan mudah menangkap sebuah materi yang diangkan dalam video tersebut. Tujuannya untuk mengembangkan kemampuan kognitif dengan memberikan rangsangan berupa gambar bergerak dan suara, serta menyampaikan pesan untuk mempengaruhi sikap dan emosi. Dalam penggunaan media audio visual ini memiliki kelemahan dan kelebihan. Oleh sebab itu, penggunaannya perlu mempertimbangkan berberapa aspek penting yang menunjang kebersilannya.

Untuk memperoleh keberhasilan dalam proses pembelajaran menggunakan media audio visual direkomendasikan agar:

1. memberikan pengalaman belajar bagi peserta didik;

2. jika akan menggunakan media audio visual sebaiknya video sesuaikan dengan materi dan tingkat perkembangan peserta didik;

3. menyiapkan kondisi peserta didik sebelum penayangan video;

4. menindak lanjuti melalui pemberian pertanyaan kepada anak berkaitan tayangan video tersebut. 


\section{DAFTAR PUSTAKA}

Anderson, Ronald. (1994). Pemilihan dan Pengembangan Media Audio Visual. Jakarta: Grafindo Pers

Daryanto.(2010). Media Pembelajaran. Yogyakarta: Gava Media

Hermawan, Asep H, dkk. (2009). Media Pembelajaran. Bandung: UPI Press

Sanaky, AH, Hujair. (2011). Media Pembelajaran Buku Pegangan Wajib Guru dan Dosen. Yogyakarta: Kaukaba

Sistem Pendiidkan Nasional.(2003). UU RI No. 20 Th. 2003 tentang sistem Pendidikan Nasional. Bandung: Fokusmedia 